\title{
Evaluating Construction Challenges of Private Housing Developers within Various Income Areas of Jos Metropolis
}

\author{
Achoru Afam Mike, Ashen Musa Jacob
}

Department of Estate Management, Faculty of Environmental Sciences, University of Jos, Nigeria.

\begin{abstract}
Housing is said to be a crucial/basic need for humans just as food and clothing. Housing Construction challenges have over the years led to limited housing development and supply. This work evaluates these challenges within various residential income areas of Jos metropolis and tries to proffer solutions via recommendations. The income areas include Rayfield, G.R.A and Gold \& Base (High Income). Millionaires quarters, Lamingo and Rock Heaven (Middle income) while Jenta, Gada Biu, Rikkos, Hwolse and Angwan Rogo represented the low income areas. A structured questionnaire containing housing construction challenges was designed for the study. 90 copies were distributed to staff of Jos Electricity distribution company (JEDC) (30 for high, 30 for middle and 30 for low income areas) and 90 retrieved. Data analysis tools used were percentage score method Standard deviation/mean score calculation. Results for standard deviation, mean score values and ranking of challenge factors are provided via tables for the various income areas. The findings are revealed and recommendations to curb these challenges are proffered.
\end{abstract}

Keywords: Housing, Construction, Challenges, Income Areas.

\section{INTRODUCTION}

Housing (Shelter) is unarguably one of the basic necessities of man. It used to be ranked second after food in the hierarchy of man's needs but according to Ebie (2009) it is the first and most important of all rights. Ebie (2009) further expressed that because of the importance attached to provision of housing and coupled with the fact that housing in all its ramifications is more than mere shelter since it embraces all social services and utilities that go to make a community or neighbourhood a liveable environment, it is now a right. Affordability refers to people's ability to purchase essential (or basic) goods and services, such as adequate housing, healthy food, and medical care (Olotuah, 2009). This however is hindered by construction challenges in the process of housing development. This further implies that basic amenities and policies can be made available to regulate, control and effectively hasten housing development process (Peterside, 2005). Peterside (2005) further expressed that challenge of housing construction range from one income level to another. Enlightenment on these challenges will go a long way to determine investment decision making. In order for housing to be achieved at all levels, its process must overcome construction challenges (Peterside, 2005).

The term private housing development refers to the creation of housing for a person or group of people either through direct construction or by contract/ extended labour services. Affordable housing is a term used to describe housing units whose total housing costs are deemed "affordable" to a group of people within a specified income range. This in turn means that challenges would have been overcome during the process of construction. When a person's income level does not match the housing construction project about to be embarked on, numerous challenges are will definitely occur which may lead to project delay or abandonment (Kanu, 2012). In Nigeria, qualitative private housing has been and is still an illusion to lower and middle class Nigerians, as governments are not prepared to really provide affordable housing to citizens (Ajanlekoko, 2001).

\subsection{Aim And Objectives}

The aim of this study is to evaluate housing construction challenges faced by private developers in various residential income areas of Jos metropolis with a view to developing a tabular breakdown encompassing the challenges from data obtained. This will be guided with the following objectives; 
1. To identify and rate the construction challenges faced by private housing developers as perceived by high income areas of Jos Metropolis.

2. To determine and rate the construction challenges faced by private housing developers as perceived by middle income areas of Jos Metropolis.

3. To identify and rate the construction challenges faced by private housing developers as perceived by low income areas of Jos Metropolis.

4. To study findings so as to make recommendations regarding some of the various ways to curb these challenges thereby enhancing private housing development in these income areas.

\section{LITERATURE REVIEW}

\subsection{Effective Housing Construction Management}

Effective housing project construction hasn't generally been rated as one of the most pressing challenge experienced by private housing developers. It is believed to be a source that has been highly neglected. Anthony et al (2014) mentioned that the use of an integrated software program which allows housing developers to make changes to data and view the changes is one way housing developers keep this challenge in check. The use of a friendly software system enabling private housing developers or their immediate contractors to view the same numbers and any changes to data as they happen or has happened is crucial. The idea is to view data in order to plan properly for probable challenges ahead. On the other hand, construction managers that can equally access data are able to respond to queries easily and with accurate information. The ability to stay organized has been and will always be an ongoing challenge (Hall, 2011). Housing developers must stay organized in order to keep jobs on course, but this can be difficult when they use multiple systems to track construction information. Some private developers have outsourced construction managers to stay competitive and maintain a flexible workforce. By outsourcing a construction manager, a private housing developer will not have to hire a full time employee and will still be able to manage a private housing construction effectively (Ogu, 2001).

\subsection{Timely Housing Completion within Budget}

Timely Housing completion within Budget is a universal challenge for all private housing developers. It's is regarded as fairly high level of challenge deterring the housing market at local and international scale. Communicating with several general and heavy/highway/utility Private housing developers, information reveal that the economy plays a significant part in this issue. It's important for a developer to complete work on time in order to move on to another job and generate revenue from the already completed job. Most individual housing developers definitely have fewer budgets to work with at present considering the current state of the economy (Pugh, 2001). With a reduced budget, financial maximisation is required. In light of this, some individual housing developers have enlisted the help of construction scheduling software to keep work on track. Scheduling software allows developers to build within a certain time frame.

It comes as no surprise that completing a job on time translates to cost savings. According to (Ikejio for, 1997), "The longer a job goes on the less profitable it becomes because developers would have higher overhead. The longer it goes on the more overhead developers have and the more costly housing development becomes." The duration of the housing project can also be an issue. Ofori (1996) expressed that if private developers do a lot of shorter duration housing projects, staying on budget can be a challenge for it is easy for a short term project to run over schedule and on the other hand harder to stay on budget when projects get extended. Staying on schedule through the use of specific construction scheduling software or other forms of scheduling is vital to getting housing construction done on time and on budget.

\subsection{Housing Pre-Construction Collaboration}

This only occurs when an individual housing developer engages the services of a construction company to embark on a project. Pre-construction collaboration is the work that goes on before a housing project begins. Issues that interfere with collaboration include: new employees learning a company's software, a contractor not fully anticipating a clients'/project's needs, and stakeholders not committing to a schedule that everyone involved in the project must use. Hill and Bowen (1997) mentioned that pre-construction collaboration is said to be a challenge when you have to make sure everybody is on the same page and learns how to use the software." To encourage pre-construction 
collaboration, contractors must be to be able to anticipate a project's needs accurately and have an understanding of what clients want. This allows for more effective communication at the start of a job and lets contractors get to work faster. Contractors who have long-term relationships with the individual developers report better pre-project collaboration. Jiboye (2011) further mentioned that during bidding, we know what clients are looking for and what they need therefore we don't have a hard time with pre-construction collaboration. Another contractor reported that scheduling an allhands meeting and status meetings at regularly scheduled intervals throughout a project at the outset of the job promotes collaboration at the beginning of a project (Jiboye, 2011). Setting up a preconstruction meeting with a set schedule to be followed is a welcome development. This also provides a schedule that all stakeholders must commit to. Failure to do this can lead to communication breakdown. Rwelamila et al (1999) indicated that firms can also have partnering meetings to keep a job on track." It is important to collaborate before a construction project begins and decide when to hold status meetings throughout the project to prevent delays later on.

\subsection{Limited Access to Housing Development Finance}

Development financing is one of the requirements for sustainable economic growth in any economy. The supply of finance to various sectors of the economy will promote the growth of the economy in a holistic manner and this will make development and welfare improvement to proceed at a faster rate (Lean, 2001). Most development finance initiatives involve the formulation and implementation of various policies, innovation of appropriate products and creation of enabling environment for financial institutions to deliver services in an effective, efficient and sustainable manner. Housing construction is greatly challenged by development finance availability. The progress of a housing construction process is largely dependent on available finance. Financial institutions exist whose responsibilities are to fund projects but a challenge however exists as to their readiness, willingness and ability to finance when funds are needed (Buckley et al, 2009). Bottlenecks as a result of inadequacy/insufficiency in finance supply have slowed the pace of housing development over the years.

\section{RESEARCH METHODOLOGY}

The research evaluates the challenges faced by private housing developers in different income areas of Jos metropolis. The research strategy bothered on data gathering from staff of Jos Electricity Distribution Company (JEDC). JEDC is known for large staff capacity that reside in different income areas of Jos metropolis. The income areas include Rayfield, G.R.A and Gold \& Base (High Income). Millionaires quarters, Lamingo and Rock Heaven (Middle income) while Jenta, Gada Biu, Rikkos, Hwolse and Angwan Rogo represented the low income areas. This study is a mixed design research. A survey questionnaire was prepared with questions seeking information on general challenges facing private housing developers in the income areas mentioned. A total of 90 survey questionnaires were distributed and all 90 retrieved (100\% collection rate). A purposive sampling technique was used to select the respondents. Data analysis tools used include percentage score method, Standard deviation/mean score calculation. Challenge factors are also ranked.

\subsection{Data Analysis Tools}

Data analysis tools used for the survey are as expressed;

Standard Deviation and Mean Scores

Mathematical representations of the followings as used in the analysis are as represented;

Let $X$ be a random variable with mean value $\mu$ :

$\mathrm{E}[\mathrm{X}]=\mu$

Here the operator $E$ denotes the average or expected value of $X$. Then the standard deviation of $X$ is the quantity.

$$
\begin{aligned}
\sigma & =\sqrt{E\left[(X-\mu)^{2}\right]} \\
& =\sqrt{E\left[X^{2}\right]+E[(-2 \mu X)]+E\left[\mu^{2}\right]}=\sqrt{E\left[X^{2}\right]-2 \mu E(X)+\mu^{2}} \\
& =\sqrt{E\left[X^{2}\right]-2 \mu^{2}+\mu^{2}}=\sqrt{E\left[X^{2}\right]-\mu^{2}} \\
& =\sqrt{E\left[X^{2}\right]-(E[X])^{2}}
\end{aligned}
$$

(Derived using the properties of expected value). 
In other words the standard deviation $\sigma$ (sigma) is the square root of the variance of $X$; i.e., it is the square root of the average value of $(X-\mu)^{2} .-0$

The standard deviation of a (univariate) probability distribution is the same as that of a random variable having that distribution. Not all random variables have a standard deviation, since these expected values need not exist. For example, the standard deviation of a random variable that follows a Cauchy distribution is undefined because its expected value $\mu$ is undefined.

\section{Analysis of Data}

A. Respondents Perception on Adequacy of income towards housing development

In other that the adequacy of income levels as regards construction challenges as it affects private housing development be determined, the respondents were asked if their income levels met their housing development targets without much challenges. From the answers (Generalized) provided by the respondents, $63.3 \%$ of the private housing developers affirmed that their incomes adequately met the housing construction process. 20.3\% expressed inadequacy with their income levels during the course of construction. However, $10.4 \%$ of the respondent's uncertainty as to whether their incomes adequate solved construction challenges. 6 were undecided. This analysis reveals that majority of individual developers adequately constructed with their income levels.

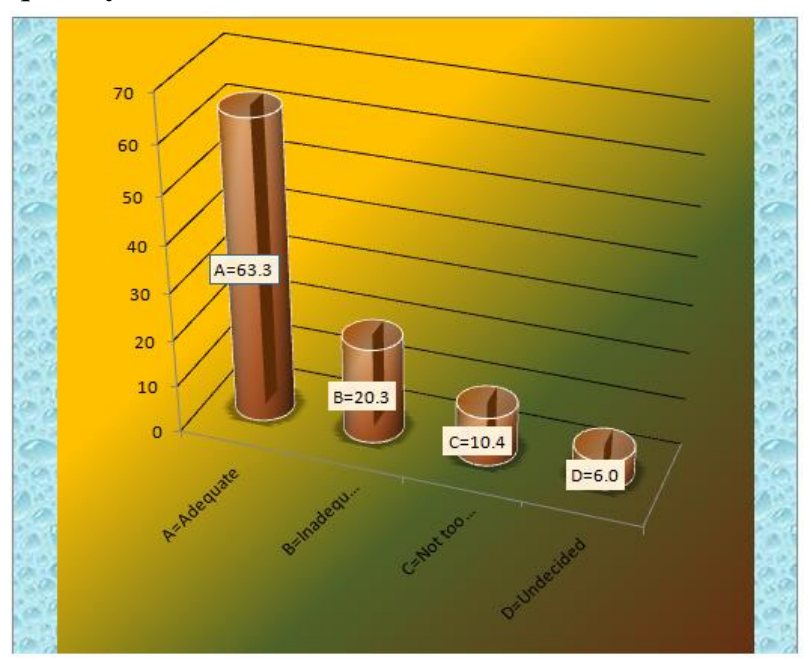

Fig1. Percentage of Respondents Perception on adequacy of income towards housing development

B. Respondents Perception on most challenged source of Housing Construction

This was aimed at determining private developer's opinion as regards the most challenged source of housing construction. Amongst the options given, 70\% opined that private developers are the most challenged in the process of housing construction, $13.5 \%$ of the respondents indicated their believe in Government being the most challenged. $6.5 \%$ were of the opinion that direct foreign investment was the most challenged. No respondent turned out undecided.

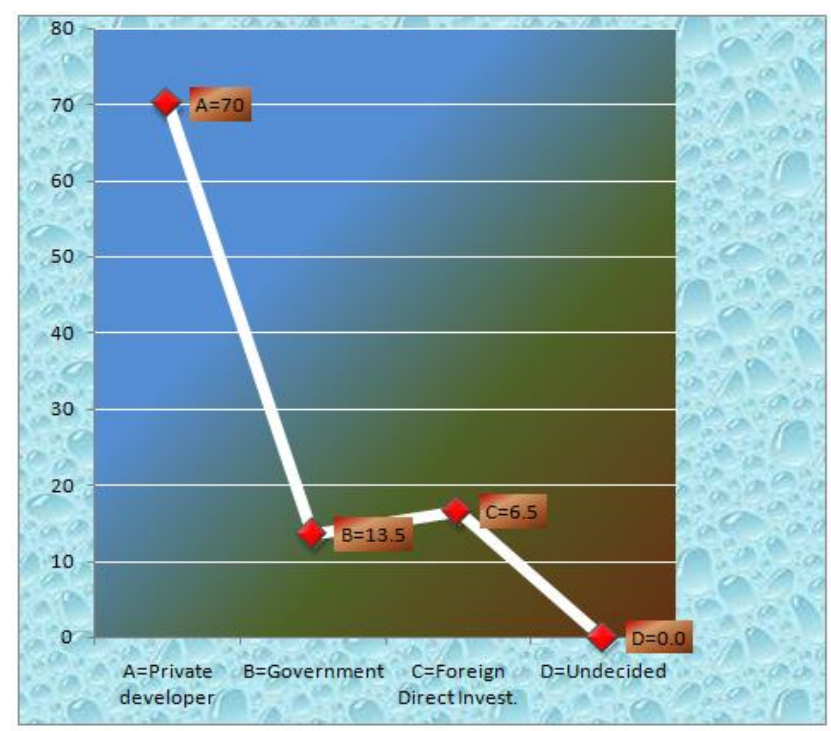

Fig2. Percentage of Respondents Perception on most challenged Source of Housing Construction 
Evaluating Construction Challenges of Private Housing Developers within Various Income Areas of Jos Metropolis

C. Percentage of Respondents' Perception on causes of housing construction delay

Housing construction delay is one major challenge that impedes housing delivery. Respondents' perception was sort on these challenges which indicated that $60 \%$ were of the opinion that financial constraint was the major cause of housing construction delay. $20.7 \%$ of respondents were of the opinion that inexperience on the path of construction workers (both skilled and unskilled) was the major cause of housing construction delay. The challenge in obtaining development permits from would-be developers had a frequency of 5.3\%. Respondents who were also of the opinion that land acquisition was the biggest challenged faced had a frequency of $10 \%$. Lastly, inadequate supervision of the housing construction process had a frequency of $4 \%$.

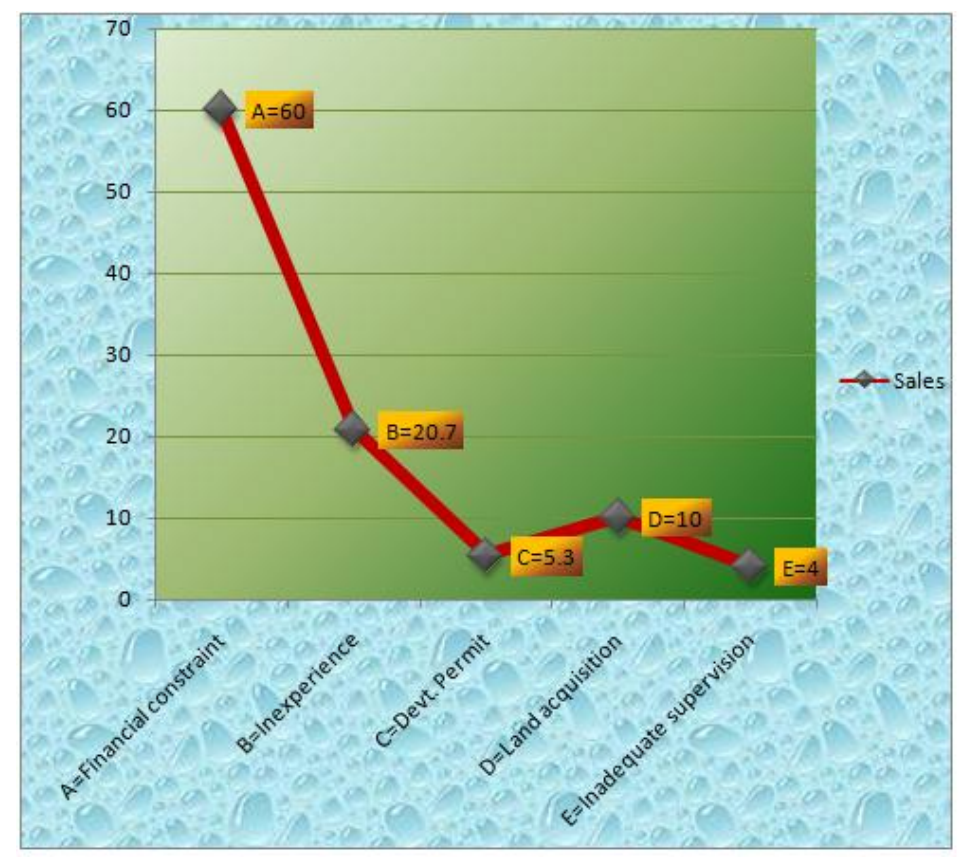

Fig3. Percentage of Respondents' Perception to Causes of Housing Construction Delay

Table1. Mean and Standard Deviation outcome for High Income Residential Areas Housing Developers on the Factors That Affect Housing Construction

\begin{tabular}{|l|l|l|l|l|}
\hline S/no & Challenge Factor Item/s & Mean & $\begin{array}{l}\text { Standard } \\
\text { Deviation }\end{array}$ & $\begin{array}{l}\text { Ranking of } \\
\text { Challenge Factor }\end{array}$ \\
\hline 1 & Availability of Land & 9.00 & 2.000 & Most Important \\
\hline 2 & Affordability of Land & 9.00 & 0.632 & Most Important \\
\hline 3 & Accessibility to Land & 8.40 & 2.272 & More Important \\
\hline 4 & Poor Land Administration & 5.40 & 2.836 & Important \\
\hline 5 & Land Development Permit & 9.80 & 0.632 & Most Important \\
\hline 6 & Access to Pipe Borne-Water & 8.20 & 2.202 & More Important \\
\hline 8 & Constant Power Supply & 9.00 & 1.700 & Most Important \\
\hline 9 & Adequate Waste Disposal System & 6.20 & 2.898 & Important \\
\hline 10 & $\begin{array}{l}\text { Ease of Access to Loans from Financial } \\
\text { Institutions }\end{array}$ & 9.60 & 1.264 & Most Important \\
\hline 11 & $\begin{array}{l}\text { Excessive High Building Standards by Urban } \\
\text { Authorities }\end{array}$ & 5.00 & 3.916 & Important \\
\hline 12 & Availability of Building Materials & 6.20 & 2.394 & Important \\
\hline 13 & Cost of Building Materials & 8.00 & 3.266 & More Important \\
\hline 14 & Use of Imported Building Materials & 9.60 & 0.844 & Most Important \\
\hline 15 & Building Standards and Modern Building Materials & 7.00 & 2.358 & More Important \\
\hline 16 & Feasibility studies on Building Production & 4.40 & 2.066 & $\begin{array}{l}\text { Moderately } \\
\text { Important }\end{array}$ \\
\hline 17 & Control of Construction Pace & 8.40 & 1.838 & More Important \\
\hline 18 & Accuracy of Project Plan Analysis & 6.00 & 2.666 & Important \\
\hline 19 & Conformity to Budget & 9.40 & 1.350 & Most Important \\
\hline & & & & \\
\hline
\end{tabular}


Achoru Afam Mike \& Ashen Musa Jacob

\begin{tabular}{|l|l|l|l|l|}
\hline \hline 20 & Spatial Building Layout in the Environment & 7.40 & 2.988 & More Important \\
\hline 21 & Effect of Urban Planning and Zoning & 8.20 & 2.202 & More Important \\
\hline 22 & Adequacy of Open Spaces for Other Land Uses & 7.20 & 2.530 & More Important \\
\hline 23 & Aesthetics and Ornamentation & 7.80 & 2.202 & More Important \\
\hline 24 & $\begin{array}{l}\text { Adequate Sanitation, Drainage, Sewage and Waste } \\
\text { Disposal; and Air quality }\end{array}$ & 8.40 & 2.066 & More Important \\
\hline 25 & Ease of Access to Basic Housing Facilities & 8.20 & 1.752 & More Important \\
\hline 26 & $\begin{array}{l}\text { Spatial adequacy and noise level within } \\
\text { Neighbourhood }\end{array}$ & 8.20 & 1.752 & More Important \\
\hline 27 & Security Issues & 9.80 & 0.632 & Most Important \\
\hline 28 & Access to Building Materials & 6.60 & 3.134 & Important \\
\hline 29 & Ease of Access to Basic Social Amenities & 9.40 & 1.350 & Most Important \\
\hline
\end{tabular}

Table2. Mean and Standard Deviation outcome for Middle Income Residential Areas Housing Developers on the Factors That Affect Housing Construction

\begin{tabular}{|c|c|c|c|c|}
\hline S/no & Challenge Factor Item/s & Mean & $\begin{array}{l}\text { Standard } \\
\text { Deviation }\end{array}$ & Ranking of Challenge Factor \\
\hline 1 & Availability of Land & 7.60 & 2.066 & More Important \\
\hline 2 & Affordability of Land & 7.40 & 1.646 & More Important \\
\hline 3 & Accessibility to Land & 6.40 & 1.264 & Important \\
\hline 4 & Poor Land Administration & 6.20 & 1.476 & Important \\
\hline 5 & Land Development Permit & 7.20 & 2.530 & More Important \\
\hline 6 & Access to Pipe Borne-Water & 9.40 & 1.350 & Most Important \\
\hline 7 & Constant Power Supply & 9.60 & 0.844 & Most Important \\
\hline 8 & Adequate Waste Disposal System & 7.80 & 1.136 & More Important \\
\hline 9 & Regular Flow of Income & 6.60 & 1.898 & Important \\
\hline 10 & $\begin{array}{l}\text { Ease of Access to Loans from Financial } \\
\text { Institutions }\end{array}$ & 6.00 & 1.334 & Important \\
\hline 11 & $\begin{array}{l}\text { Excessive High Building Standards by } \\
\text { Urban Authorities }\end{array}$ & 5.60 & 1.264 & Important \\
\hline 12 & Availability of Building Materials & 7.00 & 1.944 & More Important \\
\hline 13 & Cost of Building Materials & 6.20 & 1.464 & Important \\
\hline 14 & Use of Imported Building Materials & 5.60 & 1.264 & Important \\
\hline 15 & $\begin{array}{l}\text { Building Standards and Modern Building } \\
\text { Materials }\end{array}$ & 6.80 & 1.686 & Important \\
\hline 16 & Feasibility studies of Building Production & 5.60 & 1.264 & Important \\
\hline 17 & Control of Construction Pace & 6.00 & 1.334 & Important \\
\hline 18 & Accuracy of Project Plan Analysis & 6.00 & 1.334 & Important \\
\hline 19 & Conformity to Budget & 6.00 & 0.942 & Important \\
\hline 20 & Spatial Building Layout in the Environment & 5.40 & 0.966 & Important \\
\hline 21 & Effect of Urban Planning and Zoning & 5.40 & 0.966 & Important \\
\hline 22 & $\begin{array}{l}\text { Adequacy of Open Spaces for Other Land } \\
\text { Uses }\end{array}$ & 5.60 & 0.844 & Important \\
\hline 23 & Aesthetics and Ornamentation & 6.40 & 0.844 & Important \\
\hline 24 & $\begin{array}{l}\text { Adequate Sanitation, Drainage, Sewage and } \\
\text { Waste Disposal; and Air quality }\end{array}$ & 7.60 & 1.264 & More Important \\
\hline 25 & Ease of Access to Basic Housing Facilities & 7.40 & 0.966 & More Important \\
\hline 26 & $\begin{array}{l}\text { Spatial adequacy and noise level within } \\
\text { Neighbourhood }\end{array}$ & 5.60 & 1.264 & Important \\
\hline 27 & Security Issues & 9.80 & 0.632 & Most Important \\
\hline 28 & Access to Building Materials & 6.60 & 2.118 & Important \\
\hline 29 & Ease of Access to Basic Social Amenities & 8.80 & 1.032 & More Important \\
\hline
\end{tabular}


Evaluating Construction Challenges of Private Housing Developers within Various Income Areas of Jos Metropolis

Table3. Mean and Standard Deviation outcome for Low Income Residential Areas Housing Developers on the Factors That Affect Housing Construction

\begin{tabular}{|c|c|c|c|c|}
\hline S/no & Challenge Factor Item/s & Mean & $\begin{array}{l}\text { Standard } \\
\text { Deviation }\end{array}$ & Ranking of Challenge Factor \\
\hline 1 & Availability of Land & 6.20 & 3.190 & Important \\
\hline 2 & Affordability of Land & 8.60 & 2.118 & More Important \\
\hline 3 & Accessibility to Land & 7.20 & 1.032 & More Important \\
\hline 4 & Poor Land Administration & 5.60 & 3.502 & Important \\
\hline 5 & Land Development Permit & 6.20 & 2.574 & Important \\
\hline 6 & Access to Pipe Borne-Water & 4.80 & 2.860 & Moderately Important \\
\hline 7 & Constant Power Supply & 7.20 & 2.348 & More Important \\
\hline 8 & Adequate Waste Disposal System & 5.60 & 3.098 & Important \\
\hline 9 & Regular Flow of Income & 8.60 & 2.674 & More Important \\
\hline 10 & $\begin{array}{l}\text { Ease of Access to Loans from Financial } \\
\text { Institutions }\end{array}$ & 4.20 & 3.048 & Moderately Important \\
\hline 11 & $\begin{array}{l}\text { Excessive High Building Standards by Urban } \\
\text { Authorities }\end{array}$ & 4.40 & 3.238 & Moderately Important \\
\hline 12 & Availability of Building Materials & 7.00 & 2.538 & More Important \\
\hline 13 & Cost of Building Materials & 9.00 & 1.414 & Most Important \\
\hline 14 & Use of Imported Building Materials & 4.20 & 2.898 & Moderately Important \\
\hline 15 & $\begin{array}{l}\text { Building Standards and Modern Building } \\
\text { Materials }\end{array}$ & 6.00 & 2.828 & Important \\
\hline 16 & Feasibility studies of on Building Production & 4.00 & 2.982 & Moderately Important \\
\hline 17 & Control of Construction Pace & 6.20 & 3.190 & Important \\
\hline 18 & Accuracy of Project Plan Analysis & 7.20 & 3.190 & More Important \\
\hline 19 & Conformity to Budget & 9.00 & 1.700 & Most Important \\
\hline 20 & Spatial Building Layout in the Environment & 5.00 & 2.708 & Important \\
\hline 21 & Effect of Urban Planning and Zoning & 5.20 & 3.012 & Important \\
\hline 22 & Adequacy of Open Spaces for Other Land Uses & 5.60 & 3.374 & Important \\
\hline 23 & Aesthetics and Ornamentation & 5.80 & 3.326 & Important \\
\hline 24 & $\begin{array}{l}\text { Adequate Sanitation, Drainage, Sewage and } \\
\text { Waste Disposal; and Air quality }\end{array}$ & 7.40 & 2.836 & More Important \\
\hline 25 & Ease of Access to Basic Housing Facilities & 6.80 & 2.530 & Important \\
\hline 26 & $\begin{array}{l}\text { Spatial adequacy and noise level within } \\
\text { Neighbourhood }\end{array}$ & 7.20 & 2.150 & More Important \\
\hline 27 & Security Issues & 8.20 & 2.574 & More Important \\
\hline 28 & Access to Building Materials & 6.40 & 2.634 & Important \\
\hline 29 & Ease of Access to Basic Social Amenities & 7.80 & 1.750 & More Important \\
\hline
\end{tabular}

\section{Findings AND Conclusion}

This paper evaluates the construction challenges faced by private housing developers in different income areas of Jos metropolis. Findings show that for the challenges of high income areas, standard deviation score was highest for "ease of access to loans" at 3.916 and lowest for security issues, land affordability and issuance of land development permits at 0.632 . The middle income areas indicated the highest challenge to be "acquisition of development permit" with standard deviation of 2.530 and lowest challenge being "security issues" at 0.632. The low income areas had the highest challenge of "adequacy of open spaces for other land uses" at 3.374 and lowest of "accessibility to land" at 1.032. The challenges listed in the tables are inter-woven which tends to affect all strata of developers, therefore to comprehensively address these challenges there is need for a holistic and collective enhancement approach which will involve the Federal Government, the State Government and the private sector (both formal and informal). Government at all levels can ensure that some of the challenges like availability of land, accessibility to land, poor land administration, issuance of land development permits, ease of access to loans from financial institutions, availability of building materials and excessive high building standards by urban authorities can be eased with good policies to encourage private housing developers. 


\section{RECOMMENDATIONS}

Having digested the major challenges militating against private housing development in various residential income areas of Jos metropolis, the following recommendations are proffered;

1. The mixed use of imported building products and local products should be encouraged to reduce the high cost of construction. Also, private housing developers are advised to adopt effective and functional architectural designs.

2. The Ministry of Housing and Environment should liaise with professionals in the construction industry to organize occasional housing seminars/summits geared towards implementing the 2012 National Housing Policy and the benefits accruable thereof.

3. Government should adopt and implement strictly the provisions of 2012 National Housing Policy by providing an enabling environment for private developers to encourage an enhanced housing supply in the long run

4. The new law on the Prohibition of Fraudulent Practices on Land should be strictly enforced as youth associations resident in various construction locations harass and extort money from innocent private developers.

5. Government should review some policies/laws governing the construction sector together with and also facilitate the slow pace of justice system to reflect trends in our socio-economic environment and make investment in housing attractive.

\section{REFERENCES}

Ajanlekoko, J.S. (2001). 'Sustainable housing development in Nigeria- the financial and Infrastructural implications', International conference for sustainable development, Nairobi, 2-5, October.

Anthony B. et.al (2014), Policies and Challenges of Self-Help Housing Provision, Developing Country Studies ISSN 2224-607, 4:6, 2225-2565. Arku, G. (2009) The economics of housing programmes in Ghana: Planning Perspectives, 24 (3) 8-15.

Buckley, R., Chiquier L, and Lea M.. (2009). Housing Finance and the Economy. In L. Chiquier and M. Lea, eds. Housing Finance Policy in Emerging Markets. Washington, DC: World Bank.

Ebie, S.P.O.F.(2009). Public sector driven housing; achievements and problems. Paper presented at the 2009 Faculty of Environmental Sciences Annual lecture, Nnamdi Azikiwe University, Awka.

Hall, R. (2011). 'The many faces of the investor rush in Southern Africa: towards a typology of commercial land deals'. Initiatives in Critical Agrarian Studies (ICAS). Reviews Paper Series No. 2.

Hill, R C and Bowen, P (1997) Sustainable construction: Principles and a framework for attainment. Construction Management and Economics, 15, 223-239.

Ikejiofor, U. (1997). 'The private sector and urban housing production process in Nigeria: a study of small scale landlords in Abuja. Habitat International, vol. 21 (4) 409-425.

Jiboye, A.D (2011). Ensuring sustainable Development through Effective Housing Delivery Process in Nigeria. African Journal of Social Sciences 1(2) 36-45. Retrieved from http://www. Sacha journals.com

Kanu, K.U. (2012). 'Appraisal of the implementation of the mass housing programme in the FCT, Abuja'. Unpublished M.Sc thesis of the Department of Urban and Regional Planning, Ahmadu Bello University, Zaria.

Lean, S. C. (2001). Empirical Tests to Discern Linkages between Construction and Other Economic Sectors in Singapore. Construction Management and Economics 13:253- 262.

Ofori, G (1996) International contractors and structural changes in host-country construction industries: Case of Singapore. Engineering, Construction and Architectural Management, Vol. 3 (4) 271-288.

Ogu, V (2001). Enabling strategy and sustainable urban housing in Nigeria: Focus on Benin City, NISER Monograph Series 8, Ibadan, Nigeria Institute of Social and Economic Research. 
Olotuah, A. O. (2009). Demystifying the Nigerian urban housing question, Inaugural Lecture Series 53, delivered at Federal University of Technology, Akure, Nigeria.

Peterside C. S. (2005), Ameliorating housing deficit in Nigeria: the role of primary and secondary mortgage institutions and the capital market.

Pugh Cedric (2001). The theory and practice of housing sector development for developing countries, 1950-199, Housing Studies 16 (4) 399-423.

Rwelamila, P D, Talukhaba, A A and Ngowi, A B (1999) Tracing the African project failure syndrome: The significance of 'ubuntu'. Engineering, Construction and Architectural Management, 6 (4) 335-346. 